\title{
Guiding the
}

\section{Governor General's}

Prerogatives:

Constitutional

\section{Convention Versus}

an Apolitical

Decision Rule

\section{Bruce Hicks ${ }^{\star}$}

\section{Introduction}

On 4 December 2008, the Governor General of Canada, Her Excellency the Right Honourable Michaëlle Jean, granted a request from Prime Minister Stephen Harper for a prorogation of Parliament, just six weeks after a federal election, three weeks into the new session, and two sitting days before an opposition motion of non-confidence was likely to defeat the government and pave the way for a Liberal-led coalition government assuming power.

The media interest in this event was high because of the daily drama it offered and because of the constitutional questions it raised. While former governor general Adrienne Clarkson has since objected to the word crisis being used to describe this event, noting that "just because a resolution has to be found does not mean the situation is a crisis,"' the truth is there was sufficient uncertainty surrounding what the Governor General could, should, and might actually do that public faith in Canada's constitutional conventions and its system of responsible parliamentary government was shaken.

During the event, a number of academics were asked by the media to help Canadians understand the relevant constitutional rules and possible decision outcomes, yet the ensuing public discussion coming from the academy did nothing to alleviate the sense of uncertainty. Even after the fact, there continued to be concern about the precedent just set and lingering doubts about what the Governor General might do if, when the new session of Parliament began in January 2009, the Prime Minister again asked her to use her reserve powers, in the next instance to dissolve Parliament and call an election. This concern was so great that thirty-five academics penned an open letter recommending the course of action she should take if dissolution were proposed to her in January. ${ }^{2}$ In turn, a book on the prorogation event, entitled Parliamentary Democracy in Crisis, was released with the stated goal of helping to instruct Canadians on the principles and rules of parliamentary democracy, though the essays therein contained showed continuing disagreement on the finer points of constitutional law. ${ }^{3}$

I was one of the people called upon to provide explanations of the workings of the constitution during the event; indeed, this is a challenge for an academic at the best of times because one runs the risk of being dragged from observer to participant. This was in fact what happened several days before the fateful 4 December meeting of Canada's de facto head of state and her first minister. In one interview, carried on CTV Newsnet, I said that in spite of the often-quoted line of a governor general's role being to thwart the will of a ruthless prime 
minister (in this case, one trying to avoid a confidence vote in Parliament), the Prime Minister might successfully frame prorogation as simply a mechanism to temporarily "cool things down." After all, Parliament would still be able to vote on a motion of non-confidence upon its return in January 2009, and a viable alternative government would either still be viable, or it would have already fallen apart. ${ }^{4}$

By 3 December 2008, when the parliamentary caucuses of the political parties met in secret to plan strategy, the euphemism of a "cooling off" period had found its way into the talking points issued to the Conservative caucus by the Prime Minister's Office, and was being repeated ad nausea to the throng of media, which was now giving almost complete attention to this unfolding drama.

Over the next twenty-four hours, I had the opportunity to revisit this idea a number of times, including during the live telecast of the Governor General's decision on the morning of 4 December. ${ }^{5}$ I pointed out that what was important was not what the Prime Minister would argue but rather what the Governor General would accept. I also took the opportunity to suggest that the Governor General should be guided by the principle of doing the least harm. I drew an analogy to the way the speaker of the House of Commons casts a vote in the event of a tie, suggesting that the very reason the Governor General might be willing to accept a recommendation of prorogation was that it left the most options in play before a Parliament that would be returning one month later to deal with the confidence questions that were sure to top the parliamentary agenda (via a new throne speech and a promised budget).

A number of academics have since written about the events surrounding this prorogation, ${ }^{6}$ and several have objected to the idea of prorogation as a cooling off, arguing that such an interpretation is anathema to constitutional convention as it implies a value judgment. As Andrew Heard has put it, "considerations, such as the need for a prolonged cooling off period... are absolutely none of the governor general's concern when making a decision on constitutional grounds."7 Others have been less offended by the idea of a cooling off period, though they still emphasize that it could not have been done for a longer period of time, say more than six months. ${ }^{8}$ My do no harm analogy faired slightly better. ${ }^{9}$

These events have led me to propose the thesis at the centre of this article: that the governor general ought to use (and acknowledge the existence of) an apolitical decision rule in exercising her reserve powers or personal prerogatives. Before turning to this thesis, it is worth noting that the reason terms like cooling off and do no harm have a resonance that goes well beyond the moment is that they offer an emotional heuristic. ${ }^{10}$ That they have salience should be as much a concern to scholars as any possible misconceptions surrounding the constitution they might generate. In addition, media interest has not been only on the constitutional constraints that bind political actors, but also on the possible decision outcome, and while the academy is usually singularly interested in the former, the public is usually singularly interested in the latter. All decisions, even those constrained by clear constitutional conventions (which the reserve powers often are not), involve attention both to constitutional constraints and preferred outcomes. Perhaps, a decision matrix can offer insight into the constitutional rules at play by taking both constraints and outcomes into account.

In the days and weeks following prorogation, the merits of enunciating an apolitical decision rule became more evident. During this period, the government reconsidered its policy positions, the national executive of the Liberal Party preempted its leadership contest by anointing a leader, and the new leader of the opposition rejected the triparty coalition agreement, opting instead to support the government. Each of these political events was driven not by new developments within Parliament but by the continued lack of clarity regarding application of the relevant constitutional conventions.

Elsewhere I have argued that some of the drama could have been avoided if the Governor General has simply issued written decisions. ${ }^{11}$ While this would have eliminated the sense of crisis and provided clarity for future decisions 
in identical circumstances, it has since become apparent that we need to go further: the need is not simply for less ambiguity, it is for predictability.

A formal decision rule offers predictability. That members of Parliament (MPs) can predict how the speaker of the House of Commons will cast his or her deciding vote, for example, allows party whips and MPs to predict vote results, thereby preventing undesired defeats of legislation, particularly on matters of confidence that will precipitate a federal election. Understanding and predicting the decisions of the governor general would have similar benefits for the exact same reason. It is the purpose of this article to flesh out this idea by considering the relative merits of relying on conventions to guide the governor general's exercise of the reserve powers or adopting (or perhaps openly acknowledging) a formal apolitical decision rule.

The first part of this article deals with constitutional conventions, beginning with a review of the literature, to illustrate the inherent ambiguity that surrounds conventions in general and the personal prerogatives in particular. ${ }^{12}$ The governor general's reserve power concerning dissolution is then modeled to illustrate that, even with a minimalist approach, decisions must be taken that fall outside of such a model. The second part of the article deals with the idea of a formal apolitical decision rule, and begins with a consideration of the decision rule adopted by speakers in Parliament. While such a rule may already underlie decisions taken by the governor general, who must manage competing parliamentary interests while remaining outside of the political fray, it is only by formally enunciating the rule that ambiguity can be removed and predictability assured.

\section{Constitutional Conventions}

Sir Kenneth Wheare has advanced the classic definition of a constitutional convention as "a binding rule, a rule of behavior accepted as obligatory by those concerned in the working of the constitution." ${ }^{13}$ Building on this definition, Sir Ivor Jennings has suggested that the existence of a convention can be ascertained by asking three questions: are there precedents, is there a reason for these precedents, and do the constitutional actors involved believe that they are bound by these precedents? ${ }^{14}$ Each of these questions (that together make up the "Jennings test" for the existence of a constitutional convention) poses a particular challenge for the reserve powers, including the power to summon, prorogue, and dissolve Parliament, appoint and dismiss ministers, and withhold royal assent. ${ }^{15}$

\section{Reserve Powers}

The Supreme Court of Canada, in its Patriation Reference, used the Jennings test and stated that, for a convention to exist, the specific actors affected by the rule must have agreed to be bound by it. ${ }^{16}$ In the minority opinion, penned by then chief justice Bora Laskin, it was also argued that a convention must be clear and removed from controversy, and that it is the plenary unit that must agree to be bound. ${ }^{17}$ Nevertheless, the royal prerogative is only exercised by the governor general personally when the other constitutional actors, specifically the prime minister but also the other party leaders in Parliament, are not in agreement. These moments are always controversial; the nuances of the convention to be followed are rarely clear; and the plenary unit will be in discord. One might even characterize these instances as moments of constitutional crisis.

For the most part, the governor general quietly summons, prorogues, and dissolves Parliament (as recommended by the prime minister) without any controversy. But it is on those occasions that the governor general is called upon to reject the recommendation of the prime minister or to substitute an alternative that the exercise of the royal prerogative becomes truly personal. By definition, in these instances the relevant constitutional actors are not in agreement, and the very fact that these instances are rare means that there is a paucity of precedent upon which to base the argument that a convention exists to guide constitutional practice.

When Albert Venn Dicey first identified the existence of conventions, he observed that some "have nothing but a slight amount of custom in 
their favour and are of disputable validity," and "may be violated without any other consequence than that of exposing the Minister or other person by whom they were broken to blame or unpopularity." 18 This suggestion has been universally criticized as it runs contrary to the notion of a convention as a binding rule. ${ }^{19}$ Nevertheless, it would seem to be an apt description for the exercise of the reserve powers.

With little precedent to work with, the governor general (like all constitutional actors presumably) is guided in part by democratic theory in her exercise of the reserve powers. Indeed, Dicey himself was guided by considerations of democracy in his reckoning of conventions. His stated goal in taking what were nothing more than vague customs, imbuing them with democratic principles, and calling them a "constitutional morality" binding the Crown, was to "secure the ultimate supremacy of the electorate as the true political sovereign of the state." 20 In operationalizing this model, the convention emerged that most exercises of the royal prerogative - used by the Crown to govern should be decided by ministers who must then answer for their exercise before Parliament and before the electorate. The evolutionary nature of conventions has left some exercises of the royal prerogative in the hands of the governor general personally (the reserve powers) because there has been no agreement to allow ministers of the Crown to exercise them directly. It is argued here that the royal prerogative remains personal in these instances is to ensure it is not exercised to the advantage of any single branch of government.

Nevertheless, ministers and prime ministers have repeatedly tried to seize the reserve powers. For example, in England it has only been since British prime minister Stanley Baldwin that a prime minister has recommended the dissolution of Parliament without discussion in the full Cabinet. ${ }^{21}$ Shortly thereafter, a $1920 \mathrm{Ca}$ nadian order-in-council ${ }^{22}$ authorized the Canadian prime minister to make the recommendation for dissolution to the governor general and while this continued to be done through a minute of council, in 1957 the unprecedented invention of an "instrument of advice" emerged for this purpose to give the prime minister greater independence and exert additional influence over the exercise of the governor general's personal prerogatives. ${ }^{23}$

The very use of the word "advice" for this document is significant. With respect to exercises of the royal prerogative, a convention exists that ministerial advice should never be refused, so it is binding on the governor general. It is noteworthy that British prime minister Harold Macmillan refused to use the word advice when requesting dissolution, insisting instead that it be called a recommendation since a prime minister has "no right to advise a dissolution." ${ }^{24}$

\section{Governor General's Decision- Making Autonomy}

Disagreement over the application of constitutional conventions as they relate to the governor general's exercise of the reserve powers is not simply a question of ambitious politicians placing the monarch, and her representative, in a politically awkward position as they actively try to take over powers which they have been previously denied. Scholars too disagree about the implications of democratization for the Crown. Put simply, does democratic theory eliminate any non-ceremonial role for the monarch, rendering her a figurehead, or is there a specific political role for an unelected head of state, even a hereditary one, in a democracy?25

Figure 1 presents a continuum of possible degrees of autonomy in decision making. Legal scholars will tend to fall on the more restrained end of the continuum (suggesting a limited role for the head of state) while their political scientist counterparts will likely fall toward the less restrained end (though one of the features of constitutional conventions today is that there is disagreement over their application even when starting from similar conceptual positions). ${ }^{26}$

Sir William Anson, for example, was of the view that everything the King, or by extension the governor general, did required advice (i.e., a minister willing to take responsibility for it), noting that the King could "either convert his ministers to his point of view or, before taking 


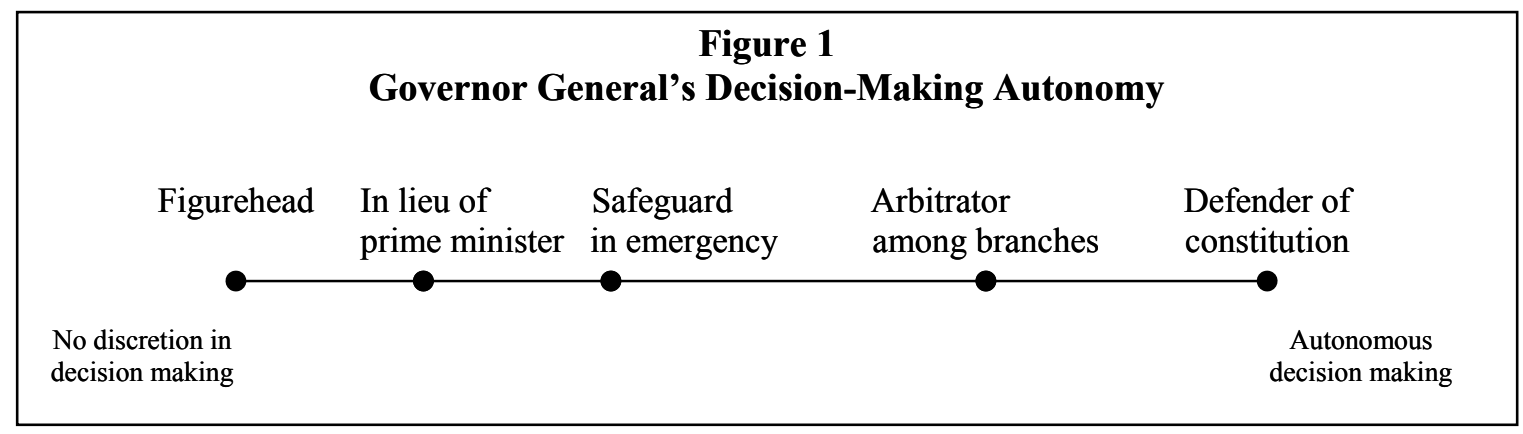

action, must find other ministers who agree with him." ${ }^{27}$ Walter Bagehot - famous for the pronouncement that a constitutional monarch has only the right to be consulted, to encourage, and to warn - thought that if there should ever be an instance when the King felt his ministers were acting against the public interest, the King should dissolve Parliament and see if the people would change the government for him. ${ }^{28}$

Even those most reluctant to acknowledge an autonomous decision-making role for the head of state are confounded by the question of who appoints a prime minister when there is a vacancy. As British prime minister Harold Wilson pointed out, an outgoing prime minister has no duty, much less a right, to recommend who should form a government. ${ }^{29}$ Berriedale Keith argued that that duty belongs to the new prime minister who is advising the Crown on his own appointment, citing British prime minister Robert Peel's claim that "I am by my acceptance of office responsible for the removal of the late government." ${ }^{30}$ The advice given to King George $\mathrm{V}$ by the lord chancellor was that potential ministers (including a possible prime minister) cannot render advice, nor can the King be bound by such. ${ }^{31}$ Jennings has rightly dismissed this idea of retroactive advice as "pure fiction." 32 Others have argued that the key to the exercise of the reserve powers is not so much the advice as it is the presence of an identifiable minister who can be held to account for the decision before Parliament and the electorate. ${ }^{33}$ Each strain of opinion is a variation on the theme of stripping the head of state of decision-making autonomy, while still permitting for eventualities in which decisions need to be taken.

In the Patriation Reference, the Supreme
Court noted that conventions are unenforceable by the courts, although they are enforced by other institutions of governance including the head of state. ${ }^{34}$ Of course even the most minimalist constitutional role for the governor general, some argue, places a decision burden on that office which goes beyond what ought to be permitted by a democratic constitution. To complicate matters, it is a role that the public perhaps expects, given the frequent invocation of the line (attributed to Eugene Forsey) that the governor general must "thwart the will of a ruthless prime minister." ${ }^{35}$ While this is a misrepresentation of Forsey's much nuanced thinking on conventions, it reflects a popular conception of the governor general's role and this, in turn, points to a very real danger. If the public has expectations for the governor general that contradict the constitutional conventions constraining exercises of the reserve powers, this can undermine the office and the conventions which are a part of our system of government. What is more, this situation is likely to get worse as the combination of Canada's electoral system and its regionalized politics continues to deliver indecisive elections. Governors general may be increasingly called upon to use their reserve powers.

\section{Modeling a Constitutional Convention as a Decision Rule}

Figure 2 reflects a minimalist approach to the governor general's exercise of the reserve powers that most scholars, irrespective of where they are on the continuum (including the thirty-five who penned the open letter in January 2009), can agree the governor general has by convention. In this construct the governor gen- 


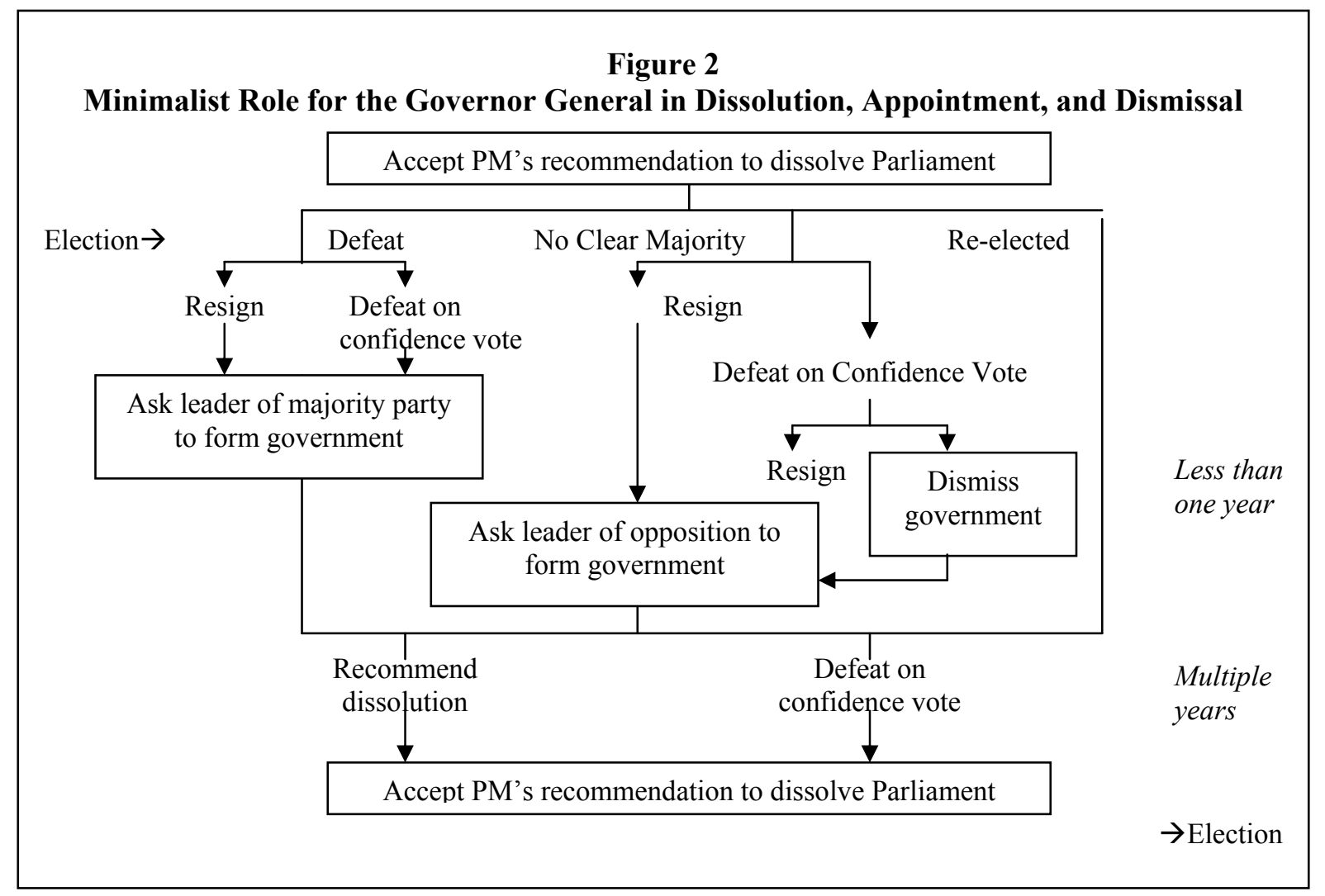

eral is called upon to exercise very little discretion. Following an election, which was called on the recommendation of the prime minister, the governor general initially does nothing. If the prime minister is moved by the election result to resign, then the governor general simply calls upon the leader of the party with the most members in the Commons, or the second most members if the prime minister's party got the most seats, to form a government. If the prime minister does not resign, even if he fails to win the most seats in the Commons, he can face the House and try to win a vote of confidence. If the prime minister is promptly defeated on a motion of non-confidence, then it is assumed by most scholars that he will then resign and the governor general, upon receiving the prime minister's resignation, will simply turn to the leader of the opposition to form a government. The involvement of the governor general in these matters is straightforward and requires no exercise of discretion.

If the prime minister meets Parliament and retains its support, then the governor general equally has no need to use discretion. At some point after a year, if the prime minister recommends dissolving Parliament the governor general simply obliges, whether or not that request came after a defeat on a parliamentary motion of non-confidence in the government. But what if this occurs before a year has passed? Here, even scholars sharing the minimalist approach disagree. The thirty-five who penned the open letter had to acknowledge that they could not agree among themselves that the governor general should call upon the leader of the opposition to form a government if a prime minister's recommendation for dissolution or defeat on a motion of non-confidence occurs within six or, perhaps as many as, nine months of the last election.

While not mentioned in the open letter, another likely point of disagreement among scholars is whether or not the governor general can dismiss a prime minister. It is always assumed that the prime minister will resign if she fails to get dissolution or if she is defeated on a motion of non-confidence. But what happens if the 
prime minister does not resign?

Of course, this minimalist view of the exercise of the personal prerogatives is not shared by all scholars. As noted in the previous section, there are those who feel the governor general should exercise no decision without advice and those who see a specific role for the head of state including a role as mediator of relations between executive and legislative branches.

\section{Complications in Conceiving Conventions as Decision Rules}

To begin with, it needs to be recognized that the minimalist role for the governor general in Figure 2 is based upon the premise that conventions are respected by all relevant constitutional actors. But the discretion constitutional convention grants the governor general in the exercise of the reserve powers is itself premised on some political actors not always respecting the rules. Not to put too fine a point on it, but the only reason to have a governor general exercise reserve powers, rather than surrender all royal prerogative to ministers who will be bound by constitutional convention, is to guard against a ruthless prime minister refusing to respect the constitution.

Constructing a decision rule out of convention thus becomes complicated. As conventions are based, in the first instance, on precedent, authors who discuss conventions are forced to examine each reserve power individually to determine the relevant precedents. Dismissal and appointment of ministers, prorogation, dissolution and summoning of Parliament, and royal assent, are all informed by precedents involving different circumstances.

For example, the last time the King considered dismissing a British prime minister was in 1913 over controversy regarding Home Rule for Ireland, though Jennings argues that dismissal would not have been constitutionally justified in that instance. ${ }^{36}$ In 1975, Australian governor general John Kerr dismissed the Whitlam government after a series of defeats on legislation in the Senate and appointed a prime minister who would recommend the dissolution of both chambers of Parliament, which he promptly did. ${ }^{37}$ Less controversially, the Australian governor general refused the recommendation of three prime ministers to dissolve Parliament after a defeat on a vote in the lower house (1904, 1905, and 1909). In Canada, a prime minister has never been dismissed; nor have governors general ever denied prorogation or commanded the summoning of Parliament without prime ministerial advice.

Without precedents to draw upon, the governor general will have to ask herself (and her personal advisors) questions before exercising her reserve powers that require a subjective foray into autonomous decision making. As Figure 3 illustrates, answering the questions the governor general must ask herself will require degrees of discretion that might be uncomfortable for some.

This list of questions is by no means exhaustive, and it is only designed to illustrate the degree of discretion that might be required of the governor general in exercising the reserve powers. It needs to be pointed out that there are a large number of even more controversial considerations that have been advanced as worthy of consideration, in addition to those mentioned in Figure 3. For example, Michael Valpy and Ned Franks suggest that the "state of Canada's economy, the viability of an alternative coalition government, and the mood of Parliament and the country" were all considerations discussed in the two-and-a-half-hour meeting that led to prorogation. ${ }^{38}$

The questions in Figure 3, however, are questions that scholars have recommended the governor general consider in an effort to shield her from making political decisions, but even here we can see a subjective dimension that could cast doubt on the nonpartisanship of the role of governor general. What is needed is a more clearly defined decision rule, one that will insulate the governor general from the accusation that she took partisan considerations into account in exercising her reserve powers. 
Figure 3

Questions that May be Considered by the Governor General in Exercising Reserve Powers

Autonomy in decision making:

Dependent on advice $\longleftrightarrow$ Personal

On appointment of a prime minister

- Does a political party have a clear majority?

- Does the leader of any party have the support of the majority of members in the Commons?

- Is there a coalition?

- Is the government viable?

On summoning Parliament

On dissolving Parliament

- Is the prime minister taking too long?

- Has the government lost a confidence vote?

- Is the request within one year of the last election?

- Is there a viable alternative government?

- Will this decision hurt the office of governor general?

On dismissing a prime minister

- Has the government been defeated on a motion of non-confidence?

- Is it within one year of the last election?

- Is there a viable alternative government?

- Will this decision hurt the office of governor general?

\section{An Apolitical Decision Rule}

The idea for an apolitical decision rule was first advanced on this side of the Atlantic in 1863 with respect to the speaker of the legislative assembly of the united province of Canada. It was proposed that on those rare instances where he was called upon to break a tie vote in the assembly he should not use his vote in a partisan manner, but rather to "keep the question as long as possible before the House in order to afford a further opportunity to the House of expressing an opinion upon it." 39 This practice was based on an earlier decision by a speaker of the United Kingdom House of Commons, and it provides a useful model for an apolitical decision rule capable of guiding not just parliamentary speakers but others institutional actors responsible for enforcing conventions, including the governor general.

\section{Precedent for an apolitical decision rule}

In the 1844 first edition of what is now the leading authority on British parliamentary privilege and practice, Sir Thomas Erskine May noted that the speaker had asserted the right to cast his vote, like any other member, "according to his conscience, without assigning a reason," though he could "best discharge his duty by leaving the bill open to further consideration." 40 In every edition of Erskine May since, the rule has taken the form that "in order to avoid the least imputation upon his impartiality, it is usual for him, when practicable, to vote in such a manner as will not make the decision of the house final, and to explain his reasons, which 


\begin{tabular}{|c|l|l|}
\hline \multicolumn{3}{|c|}{ Figure 4} \\
Application of Decision Rule to Prime Minister's Request for Prorogation (2008) \\
\hline $\begin{array}{l}\text { Decision: } \\
\text { 1) Prorogue Parliament }\end{array}$ & $\begin{array}{l}\text { Decision } \\
\text { 2) Refuse to prorogue }\end{array}$ & $\begin{array}{l}\text { Decision } \\
\text { 3) Dissolve Parliament }\end{array}$ \\
\hline Options left in Play: & Options left in play: & Options left in play: \\
-Government continues & -Confidence motion & -Government continues \\
-Confidence motion & -Government resigns & -Election \\
-Government resigns & -Coalition government & \\
-Coalition government & -Election & \\
-Opposition government & & \\
-Election & & \\
\hline
\end{tabular}

are entered in the Journals." ${ }^{\prime 1}$ In the Canadian House of Commons, this apolitical decision rule means the speaker, when obliged to vote, chooses not to defeat a bill at first reading, second reading, or committee stage, and to leave the bill in its current form rather than vote to have it amended. ${ }^{42}$

The advent of verbatim transcripts of proceedings is a relatively recent phenomenon, so the first full transcript of a speaker's ruling on this question is 1976, where the British speaker confirmed Erskine May's formulation, but also made the interesting observation that while the speaker and his or her deputies are expressly casting their votes in a manner to ensure fairness between both sides of the House, the media will inevitably refer colloquially to the chair as having cast its vote for or against the government. ${ }^{43}$

\section{Application of an apolitical decision rule}

If we look at Governor General Lord Byng's exercise of the reserve powers in the now-familiar King-Byng affair of 1926, we see a governor general deciding to leave the matter before Parliament as long as possible. He refused Prime Minister Mackenzie King's request for dissolution and, following King's subsequent resignation, allowed for the leader of the opposition to try to form a government (a process that took months rather than days). It was only when Parliament was shown to be truly dysfunctional that he granted the request for dissolution.

Figure 4 illustrates the implications of the three options before the Governor General in December of 2008: accept or refuse the Prime Minister's recommendation to prorogue Parliament, or dissolve Parliament (on this matter, at least, there was a precedent). As can be seen, the decision to prorogue Parliament had the advantage of leaving the most possibilities before Parliament. Dissolving Parliament would simply have forced a new election, and permitted the government to continue. Refusing prorogation would have left more options in play than dissolution, but there were several factors that limited these options further, including the House of Commons' rules concerning opposition votes and a signed agreement between opposition parties, so the refusal of prorogation in practice would have only left in play the appointment of the opposition leader as prime minister in a coalition government.

Did the Governor General consider the viability of the coalition? Would she, having prorogued Parliament, agree to dissolution in January were the government to be defeated, or would she appoint a coalition government? Was the fact that the Liberal leader resigned (with a leadership contest underway) a consideration in her decision to accept prorogation? Would she have been more likely to refuse dissolution of Parliament if the Liberal leadership had been settled? Indeed, it is not important that we answer any of these questions, only that we acknowledge that some doubt existed about what the Governor General might do. 


\section{Merits of an apolitical decision rule}

Having the governor general issue a written decision explaining her exercise of the reserve powers would remove a great deal of uncertainty and strengthen the constitutional conventions hedging their use. ${ }^{44}$ Having the governor general acknowledge and formalize the use of an apolitical decision rule would allow predictability in her future exercises of the royal prerogative, thereby creating a level playing field for members of Parliament.

Pointing out that an apolitical decision rule guides the governor general in her work may not eliminate the media using colloquialisms like a cooling off period to summarize the outcome of the exercise of the reserve powers, but it would go further than the current approach in claiming for the office of governor general a process that ensures impartiality and objectivity. It would also clarify for Canadians how their parliamentary system works; the very acknowledgement that the governor general is striving to keep matters before Parliament until the Commons has fully explored all options is a reminder that it is to Parliament that the government is responsible. In fact, the decision rule itself would strengthen the hand of the legislative branch by switching the scales from a process that is singularly reliant on prime ministerial recommendation to one that is centred on parliamentary accountability.

One final point should be made about coalition governments. Jennings has stated that to ensure impartiality, "[t]he rule is that on defeat and resignation of the Government the Queen should first send for the leader of the Opposition. ${ }^{35}$ On the other hand, Geoffrey Marshall has argued that in minority parliaments, having the governor general appoint a coalition government would be more in keeping with the governor general's duty to remain impartial as a coalition government would have the support of the majority of elected MPs, certainly more support than the leader of any single political party. ${ }^{46}$ The evidence supports this, as coalition governments tend to "pull the government towards the centre of the policy spectrum and reduces the distance between the government and the voters." ${ }^{37}$ An apolitical decision rule provides for the possibility of coalition governments since leaving the matter before Parliament as long as possible ensures that political parties have an opportunity (perhaps even an incentive) to explore various permutations. Yet it relieves the governor general from an overt role in the establishment of a coalition government.

\section{Conclusion}

The control of the reserve powers by constitutional convention suffers from inevitable ambiguity as they must be applied amid controversy and over the disagreement of the constitutional actors. Certainly Canada's electoral system, with the growth in regional politics and parties, has been returning more divided Parliaments, a phenomenon which is likely to continue. This means, in turn, that the governor general will be called upon more frequently to exercise the reserve powers. If the public's expectation of the governor general is that she appropriately acts on her discretion in exercising her reserve powers, then ambiguous decisions will lead to dissatisfaction with this office and with Canada's parliamentary system of government. Yet, the democratic theory informing these very same conventions points to a rather straightforward decision matrix. Put simply, to respect responsible government a governor general should naturally try to exercise her reserve powers such that as many options as possible will remain available to elected members of Parliament. This decision rule has been acknowledged to be apolitical by speakers in Parliament since before Confederation, and is used to ensure that their nonpartisan office is kept above the political fray they are periodically called upon to mediate. This approach has admittedly never been expressly adopted by a governor general, but then again, no explanation for a governor general's exercise of the reserve powers has ever been expressed formally, so even the reasons underlying convention are largely speculative.

It seems likely that governors general in the past have followed this very decision matrix, whether consciously or not. They may have been guided simply by an attempt to respect conven- 
tions though, as Patrick Monahan points out, governors general are not likely to be schooled in the constitution. ${ }^{48}$ It is more likely that governors general have been driven by a sense of fairness and a commitment to the principles of responsible government. Some may have been simply responding to a need to protect the office of which they were made temporary custodians. But each of these motives point to the existence of a decision rule such as the one elaborated here.

However, it is necessary to go further and publicly acknowledge and embrace the merits of this decision rule. This rule allows the head of state to remain above the political fray as guardian of the parliamentary system of government, as court of last resort for certain constitutional questions, and as the ultimate defender of the interests of the true political sovereign of the state - the people. For those who desire a minimalist role for the governor general, the rule removes much of the subjectivity implicit in decision making informed by precedent.

Having a formal rule enunciated will create a more level playing field so that political actors can predict outcomes, which will reduce the speculation among academics and the media that contributed to a sense of "crisis" in the December 2008 prorogation episode. It will also eliminate the need for a prime minister to stand in front of Rideau Hall and account, or fail to account, to the public for why in which the governor general's personal prerogatives have been used.

\section{Notes}

* Départment de science politique, Université de Montréal.

1 Adrienne Clarkson, "Foreword" in Peter H. Russell and Lorne Sossin, eds., Parliamentary Democracy in Crisis (Toronto: University of Toronto Press, 2009) [Parliamentary Democracy in Crisis] at xii.

2 "Le Parlement est roi, " online: Constitution Acts <http://www.constitutionacts.blogspot. com $>$. They recommended that dissolution be denied though, as noted later, they could not agree on how many months following an election this convention applied.
3 Russell and Sossin, eds., supra note 1.

4 The coalition proposal was just taking shape at the time of this comment.

5 More accurately it was a live telecast of the Governor General's front door, as everyone waited for the "possibility" of the Prime Minister emerging to announce her acceptance of his recommendation. If his recommendation for prorogation had been refused, and this is especially true if he then tendered his resignation and it was accepted, he was expected to leave by the side door and make no comments on the grounds of Rideau Hall (though one can imagine he would have had plenty to say when he returned to Parliament Hill). The governor general by tradition never makes a comment.

6 In addition to the fourteen papers published in Parliamentary Democracy in Crisis, supra note 1; and Andrew Heard, “The Governor General's Decision to Prorogue Parliament: Parliamentary Democracy Defended or Endangered?" Points of View, Discussion Paper No. 7 (Edmonton: Centre for Constitutional Studies, 2009). See also Bradley W. Miller, "Proroguing Parliament: A Matter of Convention” (2009) 20 Public Law Review 100; and Donald A. Desserud, "The Governor General, the Prime Minister and the Request to Prorogue" (2009) 3:3 Canadian Political Science Review 40. In addition, LawNow published a number of papers on prorogation in its November 2009 edition, online: <http://www.thefreelibrary.com/LawNow/2009/November/1-p5672>.

7 Andrew Heard, “The Governor General’s Decision to Prorogue Parliament: A Dangerous Precedent," online: <http://www.sfu.ca/ aheard/ elections/prorogation-2008.html $>$.

8 Jack Stilborn, “The Role of the Governor General: Time to Revisit the Visits" (2009) 30:7 Policy Options at 100.

9 It was adopted by Andrew Heard, “The Governor General's Suspension of Parliament: Duty Done or a Perilous Precedent?" in Russell and Sossin, eds., supra note 1 at 51.

10 For a discussion of how emotional heuristic might operate see Bruce M. Hicks, "Do Large-N Media Studies Bury the Lead, or Even Miss the Story?" (2009) 3:2 Canadian Political Science Review 89.

11 Bruce M. Hicks, "Lies My Fathers of Confederation Told Me: Are the Governor General's Reserve Powers a Safeguard for Democracy?" (2009) 25 Inroads: The Canadian Journal of Opinion 60. [Hicks, "Reserve Powers"].

12 This ambiguity was acknowledged to exist as far back as A.V. Dicey when he first posited the 
existence of unwritten constitutional conventions. Albert Venn Dicey, Introduction to the Study of the Law of the Constitution, 10th ed. (London: Macmillan, 1865) [Dicey] at 422. John Stuart Mill had in 1861 suggested the existence of "unwritten maxims" of the constitution. See J.S. Mill, Considerations on Representative Government (Chicago: Henry Regnery, 1961). There are a number of threads of Dicey that can be traced back to nineteenth-century writers. See O. Hood Phillips, "Constitutional Conventions: Dicey's Predecessors” (1966) 29 Modern Law Review 137. Clinton Wheare, Modern Constitutions (Oxford: Oxford University Press, 1951) at 179. For a study specifically of Canadian conventions, see Andrew Heard, Canadian Constitutional Conventions: The Marriage of Law and Politics (Oxford University Press, 1991).

14 Ivor Jennings, The Law and the Constitution, 5th ed. (London: University of London Press, 1960) at chapter 3 .

15 Some of these prerogatives, such as withholding royal assent, are argued to no longer exist due to the negative precedent that they have not been used in recent years. This is the case made over the powers of disallowance and reservation. See for example, Peter W. Hogg, Constitutional Law of Canada, 4th ed. (Scarborough: Carswell 1997) [Hogg, Constitutional Law] at 120. However, caution should be urged as this was also the position scholars took concerning section 26 of the Constitution Act, 1867 (U.K.), 30 \& 31 Vict., c. 3, reprinted in R.S.C. 1985, App. II, No. 5. Eugene Forsey called this section the "Cheshire cat" of the Constitution, yet Prime Minister Brian Mulroney was able to convince the Governor General and the Queen to use this clause to appoint additional senators in 1990 so as to ensure passage through the Senate of the goods and services tax.

This was a higher level of concurrence than originally advocated by Jennings, and was suggested by Hogg, Constitutional Law, ibid. at 9. See Reference re: Amendment of the Constitution of Canada, [1982] 1 S.C.R. 753 [Patriation Reference] at 878-80. Jennings is explored in greater detail in Re: Objection by Quebec to a Resolution to amend the Constitution, [1982] 2 S.C.R. 793 [Objection by Quebec].

17 Patriation Reference, ibid. at 760.

18 Dicey, supra note 12, footnote 26.

19 See Geoffrey Marshall, Constitutional Conventions: The Rules and Forms of Political Accountability (Oxford: Clarendon Press, 1986) [Marshall]. tions are shaped by emerging and evolving ideas of the nature and legitimacy of government. See W.S. Holdsworth, "The Conventions of the Eighteenth-Century Constitution” (1932) 17 Iowa Law Review 161.

21 Baldwin "consistently increased the importance of the prime minister by transferring definitely to his office control of the discretionary power of the Crown." See A. Berriedale Keith, The King, the Constitution the Empire and Foreign Affairs: Letters and Essays 1936-7 (London: Oxford University Press, 1938) at 41.

22 Ibid.

23 When asked about this change in the House of Commons, the parliamentary secretary to the prime pinister claimed that the earlier mechanism of conveying the recommendation through a formal "minute of Council was considered inappropriate as a means of addressing the Governor-General on those matters on which the tendering of advice is the responsibility of the Prime Minister alone and not of the Committee of the Privy Council." Canada, House of Commons Debates vol. 4 (4 April 1966) at 3776 (John R. Matheson). No explanation was given for how this had become a prime ministerial responsibility in Canada, or how a new and creatively named "instrument of advice" could emerge within the codified system of privy council documentation inherited from the British.

24 Harold Macmillan, Riding the Storm 1956-1959 (London: Macmillan, 1971) at 750.

25 This is a debate that equally underlies discussions over the powers of the judiciary and over the appropriate role for the Senate in Canada.

26 Ironically, this legal scholar/political scientist positioning is reversed in the debate over the role of the courts relative to Parliament, with Canadian political scientists tending to argue for a more limited judicial role. See for example, F.L. Morton and Rainer Knopff, The Charter Revolution and the Court Party (Peterborough: Broadview Press, 2000); Christopher Manfredi, Judicial Power and the Charter: Canada and the Paradox of Liberal Constitutionalism (Don Mills: Oxford University Press, 2001), and contrast legal scholars Peter W. Hogg, “The Charter Revolution: Is it Undemocratic?” (2002) 12 Constitutional Forum constitutionnel 1; and Kent Roach, "Constitutionalism and Commons Law Dialogues Between the Supreme Court and Canadian Legislatures" (2001) 80 Canadian Bar Review 481. This might suggest a bias for particular institutions.

27 Marshall, supra note 19 at 20.

28 Walter Bagehot, The English Constitution (Cam- 
bridge: Cambridge University Press, 2001).

29 Harold Wilson, The Governance of Britain (London: Harper Collins, 1977) at 22.

30 Berriedale Keith, The British Cabinet System (London: Stevens, 1951) at 449.

31 Harold Nicolson, King George the Fifth: His Life and Reign (London: Constable, 1952).

32 Ivor Jennings, Cabinet Government (London: Cambridge University Press, 1961) [Jennings] at 449.

33 Andrew Heard, “The Governor General's Suspension of Parliament: Duty Done or a Perilous Precedent?" in Russell and Sossin, eds., supra note 1 at chapter 4 .

34 Patriation Reference, supra note 16 at 881-83. This was affirmed in Objection by Quebec, supra note 16 at para. 98.

35 See for example, W.T. Stanbury, "Write it Down: Codify the Unwritten Conventions for Canada's Sake" The Hill Times (15 December 2008); and Larry Zolf, "Boxing in a Prime Minister" CBC News (28 June 2002), online: CBC <http://www. cbc.ca/news/viewpoint/vp_zolf/20020628.html >.

36 Jennings, Cabinet Government, supra note 34 at 412.

37 John Kerr, Matters for Judgement: An Autobiography (London: Macmillan Press, 1978); and Gough Whitlam, The Truth of the Matter (New York: Penguin, 1979).

38 Michael Valpy, "The Crisis: A Narrative" in Parliamentary Democracy in Crisis, supra note 1 at 16.

39 Journals of the Legislative Assembly of the United Province of Canada (Ottawa: Queen's Printer for Canada, 19 August 1863) at 33.

40 Thomas Erskine May, A treatise upon the law, privileges, proceedings, and usage of Parliament (London: Charles Knight \& Co., 1844) at section 218. His citation was a speaker's ruling of 4 June 1821.

41 William McKay, ed., Erskine May's Treatise on The Law, Privileges, Proceedings and Usage of Parliament 23rd ed. (Markham: LexisNexis Butterworths, 2004) at 413.

42 Robert Marleau and Camille Montpetit, House of Commons Procedure and Practice (Montreal: McGraw, 2000) at 268-69.

43 U.K., House of Commons Debates, vol. 919 (11 November 1976) at cc.662.

44 Hicks, "Reserve Powers," supra note 11.

45 Jennings, Cabinet Government, supra note 36 at 32.

46 Marshall, supra note 19 at 34.

47 André Blais and Marc André Bodet, "Does Proportional Representation Foster Closer Con- gruence Between Citizens and Policymakers?" (2006) 39:10 Comparative Political Studies 1243.

48 Patrick Monahan, Constitutional Law (Toronto: Irwin Law, 2002) at 79. 